\title{
Molecular characterization of oil seed Brassica using RAPD markers
}

\author{
M. Islam ${ }^{1}$, A. Habib ${ }^{1}$, S. Khan ${ }^{1}$, S. Akter ${ }^{1}$, B. Goswami ${ }^{1}$, H. Khan ${ }^{2}$ and T. A. Banu ${ }^{1 *}$ \\ ${ }^{I}$ Plant Tissue Culture Section, Biological Research Division, Bangladesh Council of Scientific and Industrial Research \\ (BCSIR), Dhaka 1205, Bangladesh \\ ${ }^{2}$ Department of Biotechnology and Genetic Engineering, Islamic University, Kushtia-7003, Bangladesh
}

Received: 26 October 2017

Revised: 11 June 2019

Accepted: 01 July 2019

DOI: https://doi.org/10.3329/bjsir.v55i1.46726

\begin{abstract}
Twelve varieties of oil seed Brassica spp. were characterized at molecular level using Random Amplified Polymorphic DNA (RAPD) primers to explore genetic diversity and to find out relationship among them. Twelve random primers used in the study generated 94 RAPD fragments and $53(56.38 \%)$ of them were considered as polymorphic indicating high level of polymorphism within the materials. The size of amplified fragments ranged between 300-3000 bp. The values of pair-wise genetic distance ranged from 0.1613 to 0.5543 . To find out phylogenetic relationships among the varieties, dendrogram based on Nei's genetic distance was constructed using Unweighted Pair Group Method of Arithmetic Means (UPGMA) separating the 12 Brassica spp into two major clusters $\mathrm{C}_{1}$ and $\mathrm{C}_{2}$. This result will be useful for designing future breeding programmes for improvement of Brassica varieties.
\end{abstract}

Keywords: Brassica; RAPD markers; PCR; Polymorphisms

\section{Introduction}

Economically, Brassica (Fam.: Brassicaceae) is categorized into oilseed, vegetable and condiment crops (Ghosh et al., 2009). Oilseed Brassica ranks third after soybean and palm oil in the global production (McVetty and Duncan, 2015). In this sub-continent three species of Brassica, namely, rapeseed, (Brassica rapa, Syn. Brassica campestris L.); mustard (Brassica juncea L. and Brassica napus L.) are cultivated for the production of oil. The varieties of $B$. nigra and $B$. carinata are also known as mustard but it is not commercially cultivated in Bangladesh. Brassica represented by rapeseed and mustard plays a vital role in vegetable oil production in Bangladesh. It is the most important edible oil crop, which covers the highest acreage of $66 \%$ of the total oil seed acreage of Bangladesh (BBS, 2010). This crop is mostly grown under residual soil moisture in winter season and due to the lack of using improved varieties as well as poor cultural practices, the average yield is quite lower than that in the developed countries (Hasanuzzaman et al., 2008).
The probable origin of Brassica was in the Mediterranean-middle eastern area and a secondary centre of origin and differentiation of the species B. rapa and B. juncea was appears in China (Nishi, 1980). Since their introduction into China thousands of years ago, these two species have remarkably been changed in forms, structure and productivity by domestication. As a result of the allogamous breeding system in Brassica, there is a large amount of morphological variability in the many sub-species, botanical varieties and cultivar groups of $B$. rapa and $B$. juncea $(\mathrm{Li}$, 1981; Lee, 1982; Opena et al., 1988).

Therefore, assessment of genetic variability is a first step for the future breeding program specially like these naturally synthesized complex crop species Brassica. Improvements through genetical manner have largely been contributed to the high productivity of many crops. However, breeders tend to concentrate on specific genotypes, which combine traits of 
interest and could be used as progenitors in several breeding programs. With the development of a wide range of molecular techniques, marker assisted breeding is now used to enhance flexibility, selection of the breeding materials of conventional breeding programs in crop improvement (Frey et al., 2004; Lu et al., 2004). Among them, RAPD markers, generated by the polymerase chain reaction (PCR) has widely been used to assess intra-specific genetic variation at molecular level (Williams et al., 1990). In some recent studies on Brassica crops, RAPD technique has successfully been used to determine the genetic relationships with different related species (Ren et al.,1995); to identify cultivars ( $\mathrm{Hu}$ and Quiros, 1991) and genetic diversity analysis among the crop germplasm ( Teklewold and Becker, 2006; Ahmad et al.,2009). Moreover, the main advantages of RAPD over other molecular methods are the low sample DNA requirements, high frequency of detectable polymorphic DNA bands and independent from the effects of environmental factors (Kuras et al., 2004).

Although there are many varieties of Brassica spp. available in Bangladesh, but the present varieties are mostly characterized on the basis of their morphological features.Therefore, an authentic characterization and streamlining of these varieties are needed. RAPD is an efficient method for varietal identification, study of polymorphism, gene mapping, biodiversity, genetic map construction, hybridization and phylogenetic relationship in mustard varieties (Sharma and Sharma, 1999). The aims of the present study were to characterize the varieties of Brassica spp. which are commonly grown in Bangladesh using RAPD primers. The main goal was to elucidate the phylogenetic relationship among Brassica spp on the basis of their molecular data by PCR based RAPD technique.

\section{Materials and methods}

A total of 12 varieties of Brassica spp. namely Brassica campestris var. BARI Sarisha-1 (Tori-7), Brassica juncea var. BARI Sarisha-2 (Rai-5), Brassica campestris var. BARI Sarisha-6 (Dhali), Brassica campestris var. BARI Sarisha-9 Brassica juncea var., BARI sarisha-10, Brassica juncea var. BARI Sarisha-11, Brassica campestris var. BARI Sarisha-12, Brassica napus var. BARI Sarisha-13, Brassica campestris var. BARI Sarisha-14, Brassica campestris var. BARI Sarisha-15, Brassica juncea var. BARI Sarisha-16 and Brassica campestris var. BARI Sarisha-17 were investigated in this study. These 12 varieties of Brassica were collected from Bangladesh Agricultural Research Institute (BARI), Gazipur. The experiment was performed in the Tissue Culture Laboratory of Bangladesh Council of Scientific and Industrial Research, (BCSIR), Dhaka-1205. To extract genomic DNA, young and actively growing fresh leaves were collected from each of the 12 varieties of Brassica spp. seedlings. Total genomic DNA was extracted by using a modified CTAB method (Doyle and Doyle, 1987). DNA quality was checked by electrophoresis in 1\% agarose gel and quantified through a spectrophotometer (Analylikjena, Specord 50, Germany) at $260 \mathrm{~nm}$ wave length.

To perform RAPD analysis, seventeen decamer primers (Operon Technology, USA and Sigma, USA) were applied of which twelve primers exhibited good quality banding patterns and sufficient variability. These twelve primers were selected for further analysis. The details of the twelve primers were given in Table I.

\section{Table I. Twelve arbitrary primers (RAPD primers) used in the present study}

\begin{tabular}{lccc}
\hline Primer code & Sequence $\left(5^{\prime}-3^{\prime}\right)$ & Anneal. temp. $\left({ }^{\circ} \mathrm{C}\right)$ & $\mathrm{G}+\mathrm{C}$ content $(\%)$ \\
\hline OPA-1 & CAG GCC CTT C & 36.4 & 70 \\
OPA-2 & TGC CGA GCT G & 40.7 & 70 \\
OPA-4 & AAT CGG GCT G & 35.1 & 60 \\
OPA-5 & AGG GGT CTT G & 32.6 & 60 \\
OPA-6 & GGT CCC TGA C & 35.2 & 70 \\
OPA-7 & GAA ACG GGT G & 34.1 & 60 \\
OPA-10 & GTG ATC GCA G & 33.1 & 60 \\
OPG-02 & GGC ACT GAGG & 33.6 & 70 \\
OPG-19 & GTC AGG GCA A & 34.7 & 60 \\
UBC-3 & CCT GGG CTT A & 35.2 & 60 \\
UBC-336 & GCC ACG GAG A & 39.8 & 70 \\
UBC-355 & GTA TGG GGC T & 32.7 & 60 \\
\hline
\end{tabular}


The following components were used to prepare $25 \mu \mathrm{l}$ PCR cocktail-Taq buffer A 10x (10 mMTris-HCl with1.5 mM $\left.\mathrm{MgCl}_{2}\right)-2.5 \mu \mathrm{l}$; primer $(10 \mu \mathrm{M})-1.0 \mu \mathrm{l}$; dNTPs mix $(10$ $\mathrm{mM}$ ) - $0.5 \mu \mathrm{l}$; Taq DNA polymerase $(5 \mathrm{U} / \mu \mathrm{l})$ - $0.2 \mu \mathrm{l}$; Template DNA (25 ng/ $\mu \mathrm{l})-2 \mu \mathrm{l}$ and sterile de-ionized distilled water- $18.8 \mu$ l.DNA amplification is carried out in Thermal cycler (Applied Biosystems, USA) for 35 cycles after initial denature at $95^{\circ} \mathrm{C}$ for $5 \mathrm{~min}$, denature at $95^{\circ} \mathrm{C}$ for 1 min, annealing at $30-36^{\circ} \mathrm{C}$ for $30 \mathrm{sec}$, extension at $72^{\circ} \mathrm{C}$ for 3 min and final extension at $72^{\circ} \mathrm{C}$ for $5 \mathrm{~min}$. The amplified products were separated by electrophoresis in $1 \%$ agarose gel. DNA bands were observed on UV-transilluminator and photographed by a gel documentation system (MS major science UVDA). The photographs were critically examined on the basis of presence (1) or absence ( 0$)$, size of bands and overall polymorphism of bands. The scores obtained using all

\section{Results and discussion}

Twelve oligo-nucleotide primer combinations, namely, OPA-1, OPA-2, OPA-4, OPA-5, OPA-6, OPA-7, OPA-10, OPG-2, OPG-19, UBC-3, UBC-336 and UBC-355 were used for RAPD analysis of 12 Brassica varieties. Each primer combination showed different banding patterns. The 12 Brassica varieties selected for the present study represent a broad spectrum of variation for several phenotypic traits. The primer sequence, band size and banding pattern of 12 Brassica spp. varieties were shown in Table II. Fig. 1 showed the amplification profiles generated with the 12 primers across the 12 Brassica varieties.

Table. II. Compilation of RAPD analysis in 12 varieties of Brassica spp

\begin{tabular}{lcccc}
\hline Primer Sequences $\left(5^{\prime}-3^{\prime}\right)$ & Total fragment or loci & Size ranges (bp) & Number of Polymorphic loci & Polymorphisms (\%) \\
\hline CAG GCC CTT C & 12 & $300-3000$ & 8 & 66.66 \\
TGC CGA GCT C & 7 & $500-2250$ & 6 & 85.71 \\
AAT CGG GCT G & 12 & $300-2000$ & 10 & 83.33 \\
AGG GGT CTT G & 9 & $500-3000$ & 7 & 77.78 \\
GGT CCC TGA C & 2 & $1300-1600$ & 1 & 50 \\
GAA ACG GGT G & 4 & $1500-3000$ & 3 & 75 \\
GTG ATC GCA G & 13 & $250-2000$ & 3 & 23.07 \\
GGC ACT GAG G & 6 & $500-1700$ & 4 & 66.67 \\
GTC AGG GCA A & 7 & $500-2000$ & 5 & 71.43 \\
CCT GGG CTT A & 9 & $300-2500$ & 3 & 33.33 \\
GCC ACG GAG A & 3 & $500-1200$ & 1 & 33.33 \\
GTA TGG GGC T & 10 & $300-1500$ & 2 & 20 \\
Total & 94 & & 53 & 56.38 \\
\hline
\end{tabular}

primers in the RAPD markers analysis were pooled for constructing a single data matrix. This was used for estimating polymorphic loci, Nei's (1972) gene diversity, genetic distance (D) and constructing a UPGMA (Unweighted Pair Group Method of Arithmetic Means) dendrogram among the germplasm using computer program "POPGENE 32" (Version 1.32).
Only 3 common bands of two sizes (500 and $800 \mathrm{bp}$ ) were observed in three primer combinations namely OPA-2, primer-UBC-3 and primer-UBC-355 (Fig. 1: b, j and 1.). The different sized common band indicated the sharing of similar DNA fragments among 12 varieties. Although these varieties had some common RAPD bands, sufficient polymorphisms regarding RAPD fragments were observed. 

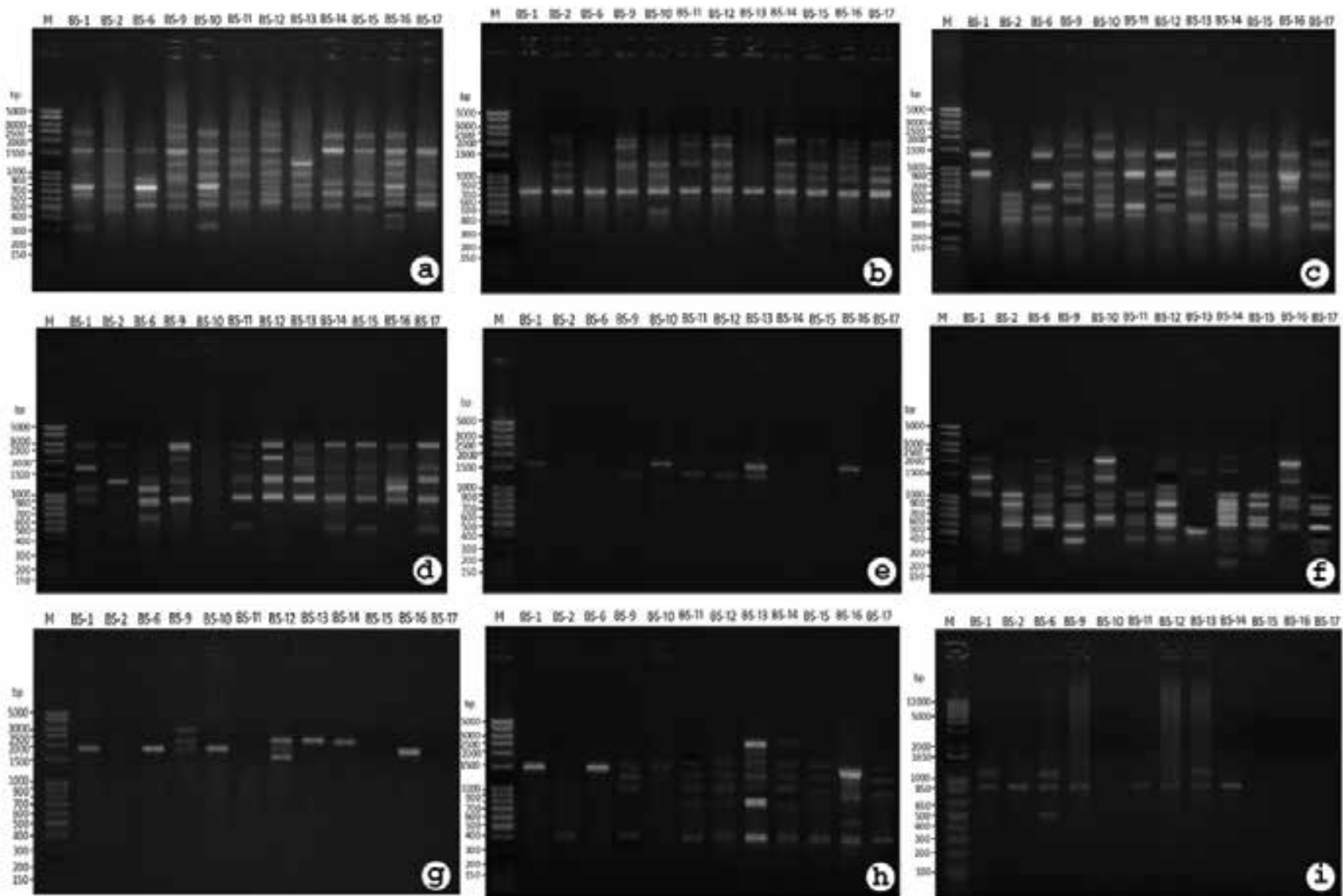

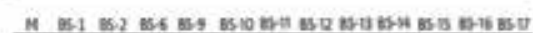
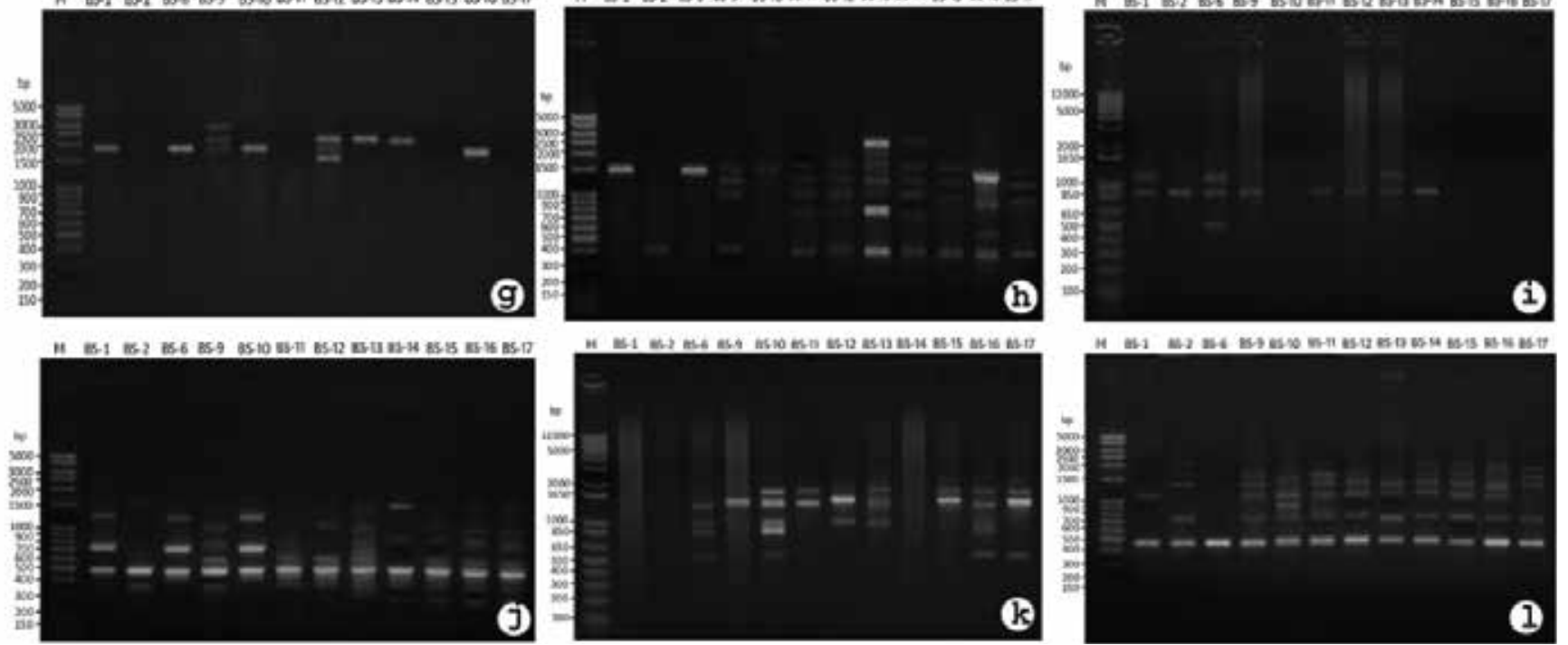

Fig. 1. RAPD analyses of 12 Brassica spp. Varieties.(a) RAPD analysis with primer OPA-1, (b) RAPD analysis with primer OPA-2, (c) RAPD analysis with primer OPA-4, (d) RAPD analysis with primer OPA-5, (e) RAPD analysis with primer OPA-6, (f) RAPD analysis with primer OPA-7, (g) RAPD analysis with primer OPA-10, (h) RAPD analysis with primer OPG-2, (i) RAPD analysis with primer OPG-19, (j) RAPD analysis with primer UBC-3 (k) RAPD analysis with primer UBC-336, (I) RAPD analysis with primer UBC-355

The twelve random primers generated 94 RAPD fragments or loci of which $53(56.38 \%)$ were considered as polymorphic and this indicated significant level of polymorphism existed within population. Ali et al. (2007) scored a significant degree of polymorphism in 15 mustard (Brassica juncea L.) germplasms using RAPD markers. The molecular weight of bands analyzed by them ranged from 100 to $7000 \mathrm{bp}$ of which $59.36 \%$ were polymorphic. Ahmad et al. (2007) reported
$59 \%$ and $60.09 \%$ polymorphism in B. napus L. and Brassica campestris L. lines, respectively. Usunova et al. (1995) observed less than $45 \%$ level of polymorphism in different varieties of Brassica napus.

The RAPD fragments size ranges were 300-3000 bp. The number of amplification products generated by each primer varied from 2 (OPA-6) to 13 (OPA-10) with an average of 
7.83 bands per primer. Primer OPA-2 showed the highest percentage of polymorphism $(85.71 \%)$ while lowest percentage of polymorphism was observed using primer UBC-355 (20\%) (Table-II). Light and bright bands were produced in the RAPD reactions. Light bands produced from low homology between the primer and the pairing site on the DNA strand (Thormann et al., 1994). Saha et al. (2008) reported the presence of polymorphic bands in nine Brassica varieties have had range from 212 to $2272 \mathrm{bp}$ in size and got highest proportion of polymorphic loci (37.29\%). Ahmad et al (2009) reported $97.70 \%$ polymorphism 20 genotypes of Brassica juncea and the amplified amplicons were ranged
Based on Nei's (1972) genetic distance, a dendrogram was prepared using UPGMA where the 12 Brassica varieties were segregated into two cluster or groups $C_{1}$ and $C_{2}$ (Fig. 2). The major cluster could be divided into two sub-cluster in which first sub-cluster included three Brassica varieties of $B$. campestris namely BARI Sarisha-1, BARI Sarisha- 2 and $B$. juncea BARI Sarisha-6 while the second sub-group included rest of the varieties (Fig. 2). The second subgroup was further divided into sub-subclasters. The values of pair-wise comparison Nei's (1972) genetic distance among 12 Brassica varieties computed from combined data from the twelve RAPD primers ranged from 0.1613 to 0.5543 (Table III). The

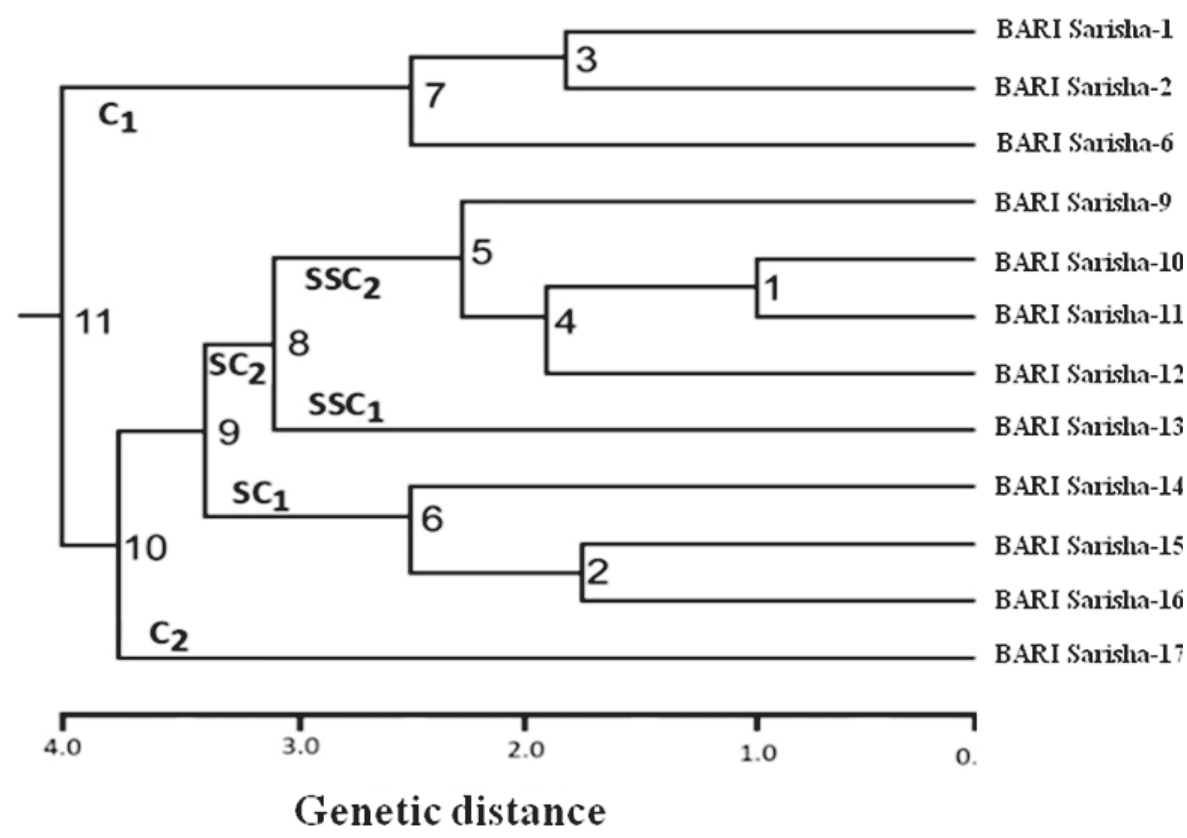

Fig. 2. UPGMA dendrogram constructed based on Nei's (1972) genetic distance summarizing data on differentiation among 12 varieties of Brassica Spp. In which, Brassica campestris var. BARI Sarisha-1 (Tori-7), Brassica juncea var. BARI Sarisha-2 (Rai-5), Brassica campestris var. BARI Sarisha-6 (Dhali), Brassica campestris var. BARI Sarisha-9, Brassica juncea var., BARI sarisha-10, Brassica juncea var. BARI Sarisha-11, Brassica campestris var. BARI Sarisha-12, Brassica napus var. BARI Sarisha-13, Brassica campestris var. BARI Sarisha-14, Brassica campestris var. BARI Sarisha-15, Brassica juncea var. BARI Sarisha-16 and Brassica campestris var. BARI Sarisha-17

from $0.1 \mathrm{~kb}$ to $5.1 \mathrm{~kb}$. A narrower range of genetic diversity has also been formerly documented by Yuan et al. (2004), Astarini et al. (2004) in B. napus and B. oleracea respectively. A diverse level of polymorphism in different crops has been reported such as chickpea 98.14\% (Rasool, 2013), peanut 96\% (Lang and Hang, 2007), eggplant 57.89\% (Biswas et al., 2009) and chilli 90\% (Paran et al., 1998). highest genetic distance (0.5543) was found between $B$. campestris var. BARI Sarisha-17 vs B. juncea BARI Sarisha-10. The lowest (0.1613) genetic distance was observed between B. campestris var. BARI Sarisha-15 vs BARI Sarisha-14. The difference between the highest and the lowest value of genetic distance revealed the wide range of variability persisting among the 12 mustard varieties. High 
Table III. Summary of Nei’s (1972) genetic distances of 12 varieties of Brassica spp

\begin{tabular}{|c|c|c|c|c|c|c|c|c|c|c|c|c|}
\hline Varieties & BS-1 & BS-2 & BS-6 & BS-9 & BS-10 & BS-11 & BS-12 & BS-13 & BS-14 & BS-15 & BS-16 & BS-17 \\
\hline BS-1 & $* * * *$ & & & & & & & & & & & \\
\hline BS-2 & 0.3386 & $* * * *$ & & & & & & & & & & \\
\hline BS-6 & 0.2126 & 0.3386 & $* * * *$ & & & & & & & & & \\
\hline BS-9 & 0.4490 & 0.2806 & 0.5179 & $* * * *$ & & & & & & & & \\
\hline BS-10 & 0.3238 & 0.4002 & 0.3238 & 0.4490 & $* * * *$ & & & & & & & \\
\hline BS-11 & 0.3689 & 0.1866 & 0.3689 & 0.2528 & 0.3689 & $* * * *$ & & & & & & \\
\hline BS-12 & 0.4658 & 0.2948 & 0.5002 & 0.1995 & 0.3092 & 0.1866 & $* * * *$ & & & & & \\
\hline BS-13 & 0.3536 & 0.4324 & 0.4490 & 0.3536 & 0.4162 & 0.3386 & 0.3092 & $* * * *$ & & & & \\
\hline BS-14 & 0.5002 & 0.2392 & 0.5002 & 0.3092 & 0.5002 & 0.2666 & 0.3536 & 0.4658 & $* * * *$ & & & \\
\hline BS-15 & 0.4002 & 0.1866 & 0.4324 & 0.2806 & 0.4658 & 0.2126 & 0.3238 & 0.4002 & 0.1613 & $* * * *$ & & \\
\hline BS-16 & 0.4490 & 0.4002 & 0.3844 & 0.5179 & 0.3844 & 0.3689 & 0.4324 & 0.5179 & 0.4658 & 0.3689 & $* * * *$ & \\
\hline BS-17 & 0.5179 & 0.2258 & 0.5179 & 0.3844 & 0.5543 & 0.3092 & 0.4002 & 0.4829 & 0.3092 & 0.1995 & 0.3536 & $* * * *$ \\
\hline
\end{tabular}

Here,

0.5543 indicates the highest genetic distance and 0.1613 showed the lowest genetic distance between two different varieties of Brassica spp.

BS-1= Brassica campestris var. BARI Sarisha-1 (Tori-7), BS-2= Brassica juncea var. BARI Sarisha-2 (Rai-5), BS-6= Brassica campestris var. BARI Sarisha-6 (Dhali), BS-9= Brassica campestris var. BARI Sarisha-9, BS-10= Brassica juncea var., BARI Sarisha-10, BS-11= Brassica juncea var. BARI Sarisha-11, BS-12=Brassica campestris var. BARI Sarisha-12, BS-13= Brassica napus var. BARI Sarisha-13,BS-14= Brassica campestris var. BARI Sarisha-14, BS-15= Brassica campestris var. BARI Sarisha-15, BS-16= Brassica juncea var. BARI Sarisha-16, BS-17=Brassica campestris var. BARI Sarisha-17.

genetic distance values between varieties pair were found due to difference in genetic constituent. The varieties of lowest genetic distance can be used as parental source for breeding line to improve mustard varieties. Ghosh et al. (2009) reported wide genetic diversity ranging from 0.049 to 0.768 among 8 genus of Brassica varieties in Bangladesh. Iqbal et al. (2015) reported genetic distance ranged from 0.1054 to 0.9862 among the 16 mustards varieties of Bangladesh according to the values of pair-wise comparison of Nei's.

\section{Conclusion}

The results of the present investigation showed high level of polymorphisms (56.38\%) among the twelve varieties of Brassica. Broad range of polymorphism revealed wide variability in Brassica spp. variety. This observed variability would be helpful for future breeding program to improve Brassica varieties in Bangladesh.

\section{Reference}

Ahmad J, Arif M, Bhajan R and Taj G (2009), Assessment of genetic diversity and genetic relationships among twenty varieties of Brassica juncea L. using RAPD markers, International J. of Biotechnol. And Biochem. 5(1): 85-92. http://www.ripublication.com/ijbb.htm

Ahmad N, Munir I, Khan IA, Ali W, Muhammad W, Habib R, Khan RS and Swati ZA (2007), PCR based genetic 
diversity of rapeseed germplasm using RAPD markers, Biotechnol. 6(3): 334-338. DOI: 10.3923/ biotech. 2007.334.338

Ali W, Munir I, Ahmad MA, Muhammad W, Ahmad N, Durrishahwar AS and Swati ZA (2007), Molecular characterization of some local and exotic Brassica juncea germplasm, African J. of Biotechnol. 6(14): 1634-1638. http://www. academicjournals.org/AJB, ISSN 1684-5315

Astarini IA, Plummer JA, Lancaster RA and Guijun Y (2004), Fingerprinting of cauliflower cultivars using RAPD markers, Australian J. Agric. Res. 55: 117-124. DOI: org/10.1071/AR03012

BBS (2010), Statistical pocket book of Bangladesh. Statistics division, Bangladesh Bureau of Statistics, Ministry of Planning, People's Republic of Bangladesh.

Biswas MS, Akhond AAY, Alamin M, Khatun M and Kabir MR (2009), Genetic relationship among ten promising eggplant varieties using RAPD markers, Plant Tiss.Cult.Biotech. 19 (2): 119-126. DOI: org/10.3329/ ptcb.v19i2.5006

Doyle JJ and Doyle JL (1987), A rapid DNA isolation procedure from small quantities of fresh leaf tissues, Phytochem. Bull. 19: 11-15.

Frey JE, Frey B, Sauer C and Kellerhals M (2004), Efficient low cost DNA extraction and multiplex fluorescent PCR method for marker assisted selection in breeding, Plant Breed. 123: 554-557. DOI: org/10.1111/j. 1439-0523. 2004.01033.

Ghosh KK, Huque ME, Parvin MS, Akhter F and Rahim MM (2009), Genetic diversity analysis in Brassica varieties through RAPD marker, Bangladesh J. Agri. Res. 34 (3): 493-503. DOI: org/10.3329/bjar.v34i3.3976

Hasanuzzaman M, Karim MF and Ullah MJ (2008), Growth dynamics of rapeseed (B. campestris L.) cv. SAU sarisha as influenced by irrigation levels and row spacing, Aust J Basic App Sci 2: 794-799.

Hu J, Quiros CF (1991), Identification of broccoli and cauliflower cultivars with RAPD markers, Plant Cell Rep 10: 505-511. DOI: 10.1007/BF00234583

Iqbal MS, Islam H, Haque S and Nath UK (2015), Genetic diversity analysis of mustard (Brassica spp.) germplasm using molecular marker for selection of short duration genotypes, African J. of Biotech. 14(17): 1439-1448. DOI: org/10. 5897/ AJB2015.14445

Kuras A, Korbin M and Zurawicz E (2004), Comparison of suitability of RAPD and ISSR techniques for determination of strawberry (Fragaria $\times$ ananassa Duch) relationship, Plant Cell, Tissue and Organ Culture 79: 189-193. DOI: 10.1007/ s1 1240-004-0659-7

Lang NT and Hang PTC (2007), Genetic divergence analysis on peanut by RAPDs, Omonrice 15: 174-178. https:// www.academia.edu/6842718

Lee SH (1982), Vegetable growing in China, Scientia Hortn 17: 201-209. DOI: 10. 1016/0304-4238(82) 90041-3

Li CW (1981), Origin, evolution, taxonomy and hybridization of Chinese cabbage In: Talekar NS, 114 Griggs TD (eds) Chinese Cabbage, AVRDC, Taiwan, pp. 3 - 11. http:// www. Fao. org/library/ library-home/en/

Lu GY, Yang GS and Fu TD (2004), Molecular mapping of a dominant genetic male sterility gene $\mathrm{Ms}$ in rape seed (Brassica napus), Plant Breed 123: 262 - 265. DOI: 10.1111/j.1439-0523.2004.00957

McVetty PBE and Duncan RW (2015), Canola, Rapeseed, and Mustard: For Biofuels and Bioproducts. In: Industrial Crops - Handbook of Plant Breeding, Chapter: 7, Springer. DOI: 10.1007/ 978-1-4939-1447-0_7

Nei M (1972), Genetic distance between populations, American Naturalist 106: 283-292. DOI: org/ $10.1086 / 282771$

Nishi S (1980), Differentiation of Brassica crops in Asia and breeding of 'Hakuran' a newly synthesized leafy vegetable, In: Tsunoda S, Hinata K, Gomez-Campo C (eds) Brassica Crops and Wild Allies, Japan Sci. Soc. Press, Tokyo, pp. 133-150 https://www. cabdirect.org/cabdirect/abstract/19810719086

Opena RT, Kuo CG and Yoon JY (1988), Breeding and seed production of Chinese cabbage in the tropicsand 
subtropics, Tech Bul 17, AVRDC, Taiwan DOI: org/10.1017/ S0014479700015210

Paran I, Aftergoot E and Shifriss C (1998), Variation in Capsicum annuum revealed by RAPD and AFLP markers, Euphytica 99 (3): 167-173. DOI: 10.1023/A : 1018301215945

Ren J, Mc Ferson JR, Li R, Kresovich S and Lamboy WF (1995), Identities and relationships among Chinese vegetable Brassicas as determined by random amplified polymorphic DNA markers, J. Amer. Soc. Hort. Sci. 120: 548-555. DOI: org/10. 21273/ JASHS.120.3.548

Rasool S (2013), Genetic diversity as revealed by RAPD analysis among chickpea genotypes, Pak. J. Bot. 45(3): 829-834. https:// www.pakbs.org/ pjbot/ PDFs/.

Saha S, Molla MR, Chandra D and Rahman L (2008), Assessment of genetic variation and relationships within the varieties of four Brassica species by RAPD markers, Aust. J. of Crop Sci. 2(3): 105-114. http://cropj.com /Microsoft\% 20Word\% 20-\%20 main $\% 20$ Sanchita $\%$ 20105-114. ISSN: 1835-2707

Sharma A. K. and A. Sharma, (1999), Plant Chromosomes Analysis Mainpulation and Engineering, Harwood Academic Publishers, Amsterdam, p. 371. ISBN 90 57023873.
Teklewold A and Becker HC (2006), Geographic pattern of genetic diversity among 43 Ethiopian mustard (Brassica carinata A. Braun) accessions as revealed by RAPD analysis, Genet.Resour. Crop Evo. 153: 1173-1185. DOI: 10.1007/s10722-005-2011-4.

Thormann CE, Ferreira E, Camargo LEA, Tivang JG and Osborn TC ( 1994), Comparison of RFLP and RAPD markers to estimating genetic relationships within and among cruciferous species, Theor Appl Genet 88: 973-980. DOI: 10.1007/BF00220804.

Usunova M, Ecke W, Weissleder K and Robbelen G (1995), Mapping of the genome of rapeseed. Brassica napus L. I. Construction of an RFLP linkage map of localization of QTLs for seed glucosinolate content, Theor. and Applied Genet. 90: 194-204. DOI: 10.1007/ BF00222202.

Williams JGK, Kubelik AE, Levak KJ, Rafalski JA and Tingey SC (1990), DNA polymorphisms amplified by arbitrary primers are useful as genetic markers, Nucleic Acids Res. 28: 6531-6535. DOI:10.1093/ nar/18.22.6531

Yuan M, Zhou Y and Liu D (2004), Genetic diversity among populations and breeding lines from recurrent selection in Brassica napus as revealed by RAPD markers, Plant Breed. 123: 9-12. DOI: org/10. 1046/j.0179-9541.2003. 00903.x 